\title{
Marketisation, Ethics and Healthcare
}

Policy, Practice and Moral Formation

\section{Edited by Therese Feiler, Joshua Hordern and Andrew Papanikitas}

\section{Covenant, compassion and marketisation in healthcare}

Joshua Hordern

(CC BY-NC-ND 4.0)

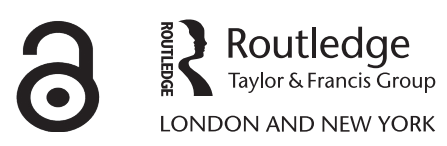


First published 2018

by Routledge

2 Park Square, Milton Park, Abingdon, Oxon OX14 4RN

and by Routledge

711 Third Avenue, New York, NY 10017

Routledge is an imprint of the Taylor \& Francis Group, an informa business

(C) 2018 selection and editorial matter, Therese Feiler, Joshua Hordern and Andrew Papanikitas; individual chapters, the contributors

The right of Therese Feiler, Joshua Hordern and Andrew Papanikitas to be identified as the authors of the editorial material, and of the authors for their individual chapters, has been asserted in accordance with sections 77 and 78 of the Copyright, Designs and Patents Act 1988.

With the exception of Chapters 4 and 7 , no part of this book may be reprinted or reproduced or utilised in any form or by any electronic, mechanical, or other means, now known or hereafter invented, including photocopying and recording, or in any information storage or retrieval system, without permission in writing from the publishers.

Chapters 4 and 7 of this book are available for free in PDF format as Open Access from the individual product page at www.routledge.com. They have been made available under a Creative Commons Attribution-Non Commercial-No Derivatives 4.0 license.

Trademark notice: Product or corporate names may be trademarks or registered trademarks, and are used only for identification and explanation without intent to infringe.

British Library Cataloguing-in-Publication Data

A catalogue record for this book is available from the British Library

Library of Congress Cataloging-in-Publication Data

A catalog record for this book has been requested

ISBN: 978-1-138-73573-6 (hbk)

ISBN: 978-1-315-18635-1 (ebk)

Typeset in Times New Roman

by Apex CoVantage, LLC 


\title{
7 Covenant, compassion and marketisation in healthcare
}

\author{
The mastery of Mammon and the \\ service of grace
}

\author{
Joshua Hordern
}

\begin{abstract}
No one can serve two masters, for either he will hate the one and love the other, or he will be devoted to the one and despise the other. You cannot serve God and Mammon.
\end{abstract}

(Matthew 6:24, ESV)

\section{Serving and measuring ${ }^{1}$}

'No one can serve two masters . . You cannot serve God and Mammon.' Jesus' famous words, cited to different purposes by Miran Epstein and Adrian Walsh in this volume, provide a starting point for this chapter's constructive argument and critical conversation with the chapters in this middle part. Epstein deploys Jesus' words to deny the possibility of any constructive reconciliation between capitalism and healthcare, contrasting Jesus' saying with the infamous words of Christian conquistadores and with what he claims is the inherently corrupting, master-slave ethic of the Deuteronomic covenant. By contrast, Walsh cites Jesus to explain JudeoChristian cultural suspicions about money's place in healthcare before delineating the potentially, though not necessarily, corrosive effects of marketisation.

Jesus' teaching suggests that determining what mastery and service mean is central to any ethically and culturally sophisticated interpretation of marketisation's multiple influences amidst the suffering which healthcare is instituted to address. Accordingly, the core insight to be taken from Feiler's and Herring's criticisms of concrete examples of marketisation within health and social care may be summarised as follows: that which we serve will be determined in part by the representation of ourselves and our neighbours to which we subscribe. Certain representations of care and of work are perpetuated by concrete forms of marketisation within health and social care, such as those Herring and Feiler explore. Values embedded within certain kinds of codification and budgetary policy master the consciousness of patients and healthcare workers. These values' effects on human relationships seem to Herring and Feiler inimical to the ethos which ought to mark the practice of health and social care.

In my view, the representations of self- and neighbour-care and of work which follow from such mastery are necessarily of political significance since the 


\section{Joshua Hordern}

healthcare institutions affected are those upon which political self-consciousness in part depends. My questions follow:

- What image of health and social care work is in fact represented by the specific cases of marketisation that Feiler and Herring have critiqued?

- What kind of political story should be told about citizens by the processes of marketisation which affect their health and social care? How should people and their caring relationships be represented?

- How should Christian pastoral and political theology answer these last two questions to enable judgments to be made between benign and malign forms of marketisation?

Critique of the representations of health and social care is an essentially pastoral and political activity. Everyday experiences of care, requiring pastoral sensitivity, are influenced by system-wide developments. Such pastoral sensitivity must also be political, informed by insight into political conditions, narratives and beliefs which shape people's lives.

The Archbishop of Canterbury, Justin Welby, analyses late liberal economic and political life in this spirit. For Welby, what is measured has come to be what matters. 'Mammon draws our gaze away from things that are more worthy of our attention but have not been given the badge of a comparable monetary value' (Welby 2016, p. 40). In short, 'what we measure controls us' (ibid. p. 35). Those worthy of our attention and service are neglected. That which we create as a quantifiable standard of success comes to master us.

This pastoral concern finds a desultory echo in the effects of a target culture on care among staff in the British NHS. As McCann et al observed in relation to one institution:

[the] targets regime was forcing [staff] to try to please two masters, and in the process incentivizing them to move in two very different directions. A middle manager in the ambulance trust explained this in a very simple phrase: "You can't do both - something will give".

(McCann et al. 2015, p. 784)

The consequences for institutional morale are unsurprising:

[the] kinds of goal displacement inscribed in the attitude of "what's measured is what matters" . . remains pervasive within the NHS. Other failings, distortions, and forms of "gaming" ... create perverse outcomes and typically result in a decline in morale for public service professionals.

(ibid. p. 777)

I will argue that covenantal modes of thought and practice, native to Jewish and Christian thought in their representations of human life, are peculiarly sensitive to that which tends not to be represented in the marketisation processes to which Feiler and Herring pay attention. Accordingly, following (1) these introductory 
remarks explaining my approach I will (2) now engage critically with the ways that care and work are represented in Herring's and Feiler's chapters. Then I will (3) build on this to develop a constructive, pastoral-political proposal focussing on the themes of covenant and compassion in order to address the issues of service, mastery, history, personalisation and responsible choice which surround processes of marketisation before (4) coming to a conclusion.

\section{The representation of care and work}

To articulate how covenantal thinking dethrones Mammon in practice, it will be helpful first to reflect on the challenges which have been analysed by Feiler and Herring. These will be categorised under two themes which define both chapters' underlying rationale.

\subsection{Care}

The commodification of care inherent in the codification of Diagnosis Related Groups and the use of personal budgets represents, most fundamentally, a risk to the representation of care. That kind of risk is fundamental because the core of a culture is formed by its loves, by the ways it comes to value that which it shares. But that which is valued, loved and shared is defined by what people perceive what is represented to the self and to the community as true about the world. Hence the risk of a false representation of care. Will what is measured so master care as to distort what ought to define the relations between persons?

DRGs, on Feiler's account, have been a chief instrument in a 'transvaluation' now embedded in ways of perceiving healthcare which simultaneously entrench and cleverly conceal from criticism the representations of the patient-as-consumer and healthcare-as-product to be delivered. A more extreme underlying transvaluation is that the patient becomes represented by the cash value of their care need - an end obscenely demoted into a mere economic means.

In manifold subtle ways, patients are made to follow or serve the money, illustrating in interpersonal relations the mastery by Mammon which Jesus warns against. However, rather than giving in to an apparently uncontrollable evolutionary process, understanding the historical processes in which marketisation occurs makes dethroning Mammon possible.

The insight of pastoral and political theology is that none of Hayek's three kinds of order which account for the development of any particular state of affairs - taxis, kosmos and catallaxy - have any regard to what Christian theology has learned to call the moral order of creation to which all 'orders of love' are called to correspond in order to enable truthful perceptions of neighbours and to restrain the distortion of care. By this account, it is a person's or institution's order of love which shapes and directs the compassion which characterises that person or institution (Hordern 2013a; cf. Hordern 2013b; Hordern 2017).

This sharpens the question of what might sustain regard, make perception truthful, restrain distortion and order compassion aright. For Feiler, the ultimate 


\section{Joshua Hordern}

consideration is the plenitudinous, generous gift of God in Christ which enables a steady polemic against and resistance to any conflation of healthcare with the logic of a market committed to the maximisation of utility and the extraction of profit. This is clearly in some tension with Petratos (2018), who has a positive and subtle approach to utility considerations in healthcare.

Personal budgets, for Herring, encourage the perception of care as a commodity to be bought and sold. The devolution of choice to the individual, intended to liberate people in their personal autonomy, becomes that by which people are enslaved, especially in their doubts, fears and worries. To put it in more sinister terms, the patients' 'value' precisely as sources of income is 'liberated' to the play of market forces.

To elaborate Herring's analysis, observe that the state, in this devolutionary process, may 'retail' certain interpretations of liberation by disseminating stories about its citizenry. One such is the tale Herring reports of the woman we might call 'Dancing Sally' who, disentangled from the leaden-footed, stumbling state, is free to jig at all hours, supported by her lively personal assistant, funded by her personal budget. Care is represented here as supporting a joyful exodus from the loneliness and inactivity which an inflexible, state-dominated, depersonalised system can impose. The policy which inspires this representation aims to energise vibrant local markets which can individually service the diverse needs of clients who choose to deploy their personal budget. The patient-asconsumer becomes the master of her care, not the servant of the constricting choices of others.

Herring, however, draws on empirical studies to paint a less than flattering picture of how this policy has created a diminished image of care with desultory effects on people's lives. Potentially negative emotional experiences have indeed been transferred to 'service-users' - a concrete example of the 'relocation' about which Feiler is concerned. For one study from the evidence Herring cites, the

implication [of the research], that people who feel negative whilst making welfare-related decisions tend towards avoiding rather than embracing these decisions, is important, especially within the context of policies that assume choice is beneficial per se and that opportunities for choice should be maximised.

(Baxter and Glendinning 2013, p. 448)

Herring and I share a fundamental concern to support caring relationships (indeed who could disagree with this?). But my question is whether some framework for the 'personalisation' of social care, within a suitably diversified market, wellpopulated with prospective employees, underpinned by the guarantee of state action for those unwilling to participate in the market directly, can support the development of a caring, compassionate polity. This is to some degree in tune with the principal positive claim of Petratos (2018), namely that the decentralisation of healthcare enables services to be better fitted to people's preferences. 
The evidence suggests that, for many, the benefits of taking control over personal budgets is principally a matter of timing. As one contented citizen in a study to which Herring refers said:

I've got my head round everything else. It's all dealt, it's all slotted into its own place, and now direct payments is a doddle. It just does not seem like a problem now. But then it did, and I wouldn't touch [it] with a bargepole because it just seemed so much work and so much time and effort.

(ibid p. 446)

So finding the right time to take control by entering the market is important. But time is also a key factor in relationships between carer and 'service-user'. For another study Herring cites, we learn that, rather than being inherently damaging to caring relationships,

[carers'] psychological well-being was significantly associated with having a regular arrangement for someone to take care of the service user to enable the carer to have a break.

(Glendinning et al. 2009, p. 79)²

More ambiguously perhaps, the study also reports that

carers reported that a service user's ability to pay a carer could contribute to positive outcomes for the IB [individual budget] user by reducing feelings of dependency and indebtedness.

(ibid. p. 94)

Just what is negative about dependency and indebtedness is not itself analysed. Perhaps it was the sense of being a burden on society and relatives, in which case the 'positive' quality of the outcome would be contested by those who believe that care is learnt through acknowledging interdependency.

Nonetheless, it is clear that direct payment for care, personalised in this way with responsibility given to those who wish to have it and with the availability of a suitably trained care workforce, can make for some kind of emotional contentment and provide much-needed relief. It is not obvious that state or local authority monopoly control of social care provision is in any way better fitted to deliver 'positive' outcomes.

The Baxter/Glendinning study summarises the overall position well by concluding with the moderate, practical observation that the evidence does not support 'an argument against devolving responsibilities, but for empowering people by offering appropriate support in all aspects of making choices' (Baxter and Glendinning 2013, p. 448).

The core problem which emerges from Herring's analysis concerns how the 'relational autonomy' he commends should interrelate with the degree of control 
exercised by the state or local authority, bearing in mind policy trends towards personalisation, choice and responsibility (personal, familial and charitable). Addressing this problem is vital when discerning whether and how caring may be well represented in marketised health and social care environments.

\subsection{Work}

The work involved in health and social care is also represented in certain ways in DRGs and personal budgets. Feiler cites Maio's view that the industrialised, standardised, hyper-efficient processes have increasingly robbed healthcare professionals of a patient, conscientious, compassionate, joyful and authoritative sense of vocation. The human freedom to do good work before God upon which a humane healthcare system depends is distracted and mastered by economic technocracy. For Herring, the logic which orders the personal budgets system cements a debasement of caring work by ignoring the nature of caring relationships. What seems to be necessary, therefore, are ideas and structures which fortify resistance to this debasing of professionalism (Roland 2012). A reassertion of vocation remains prone to failure if it is not interwoven within a socio-political consciousness, fully informed about the historic nature of developments in healthcare marketisation.

However, personal budgets clearly affirm the valuable personal work of taking care of oneself and shaping the caring relationships one enjoys. It is perhaps too easy to point to those who lack the ability to do so and for whom personal budgets are not appropriate either at all or at this time or in an unsupported fashion. Herring himself observes that no one is compelled to pursue a personal budget approach. While compulsion comes in many forms, the fact that only 5\% said that they felt pressured to do so seems a vindication of the approach, considering the potential vulnerability of those who use the service.

By contrast, the positive opportunity for some citizen-patients to share responsibility seems a significant benefit. While the pastoral care of those who feel unfitted - either always or at a particular point in time - to take such responsibility could no doubt be improved, it seems hard to deny that the work of self-care, in a supportive environment, is not empowering for some, perhaps for many or even most. The empirical evidence does not rebut this claim.

What Feiler and Herring agree is that care work is inadequately represented in the forms of marketisation they examine. Herring does not recommend dismantling the entire personal budget system, noting that it is a mixed picture in terms of outcomes. Feiler, one imagines, would welcome the liberation of healthcare from DRGs. However, her practical recommendations turn more in a diakonic direction, thus following Petratos' approach rather than Herring's (Petratos 2018, p. 29; Feiler 2018, p. 29; Herring 2018, p. 93). These critiques do not tell against any and every kind of marketisation, but they do issue a strong exhortation that the possible effects of marketisation in some circumstances should be mitigated, held in check or reversed.

What seems necessary are modes of resistance to demoralisation - to the consciousness becoming mastered by processes associated with marketisation. The 
central goal should therefore be to uphold better representations of care and work to resist debasement and strengthen what is good. In the third part, therefore, I will now turn to think about how this goal can be pursued.

\section{Covenant and compassion}

Mammon's mastery of healthcare relationships is to be resisted. But what kind of political story should be told by and about citizens to dethrone Mammon in the processes of marketisation which affect their health and care? How should people, their caring relationships and their work of care, be 'represented' in specific policy approaches? What will sustain regard, guide perception into truth, restrain distortion and order compassion aright?

The kind of representation in view here differs in an important respect from those analysed in respect of Feiler and Herring. Rather than being an unselfconscious misrepresentation of care on account of marketisation processes, the covenantal mode of representation to be explored below enables judgments to be made between benign and malign forms of marketisation. When representation of health and social care relationships are normatively presented within a 'covenant', a certain kind of story about who people are and how they ought to relate is told.

\subsection{Almsgiving and ordered loves}

The long traditions of Jewish and Christian reflection on covenant and wealth offer wisdom here. John Chrysostom, the fourth-century church father, taught that almsgiving is a powerful weapon to break the power of wealth which can master us, binding us like a chain. The way to conquer wealth, Chrysostom argues, is to distribute it: when we are isolated it binds us - 'but when we bring it forth among others, it will master us no more, holden as it will be in chains, on all sides, by all men' (Chrysostom 1839, p. 177). For Chrysostom, people are to master money by being bound together rather than being mastered and bound by it, in isolation from each other. This is not an argument against money itself as he says: 'God made nothing evil, but all things very good; so that riches too are good ... . if they do not master their owners' (ibid. p. 177). This is what 'despising' and 'hating' (Matthew 6:24) means in practice - an orientation and practice which is so conscious of the quasi-divine draw of Mammon that it requires Mammon's submission to God, 'whose service is perfect freedom' (Church of England).

For this Christian tradition, almsgiving bears witness and responds to the prior generous initiative of God, giving freely that humanity might not be enslaved to Mammon. There is a relational wisdom in the manner of God's acts of salvation which climax in the gift of Christ incarnate, crucified, risen and ascended. God's initiative invites participation in a new and covenantal mode of relating between God and humanity and among human persons - ways of being bound together through ties of grace, binding the power of other things to enslave us. 


\section{Joshua Hordern}

This covenantal wisdom lies uniquely in the mode of gracious initiative which calls forth a faithful and free response to break with Master Mammon. As Justin Welby puts it:

Dethroning Mammon requires the dramatic leap of faith of being defined by what we do not measure - cannot measure - because it is the infinitely valuable, utterly cosmos-transforming love of God in Jesus Christ.

(Welby 2016, p. 57)

The new covenant in Christ binds its parties together in a manner which both guarantees their future relationship and requires daily, responsible choices on the part of the recipients of grace. The nature of the covenant tells a certain kind of story about those who trust the promise of God which initiates the covenantal relation. They become conscious of the dangers which surround their journey through life - that wealth can master and bind their personal and institutional consciousness and practice.

On a systematic level, Rusthoven comments that its

central position in redemptive history and its relational character make the covenant theme well suited as the basis for a normative understanding of relationships within creation, including those that form in the course of medical practice and research.

(Rusthoven 2014, p. 186)

That which provides the normative structure of God's redemptive work in Israel and in Christ is in no way dissonant from the created order. In other words, God vindicates his creation through his redemptive work.

In vindicating it, God provides the basis for the benign relational life of caring Herring commends, and the distortions of perspective in DRGs which Feiler rejects. It is neither the cosmos nor taxis nor catallaxy of Hayek, but rather the created order of God, vindicated in Christ, which should discipline human relations within a certain order of love (ordo amoris). This order takes a specific form in covenantal modes of loving relations between God and human persons and among those persons, modes which bind money's power by graciously inspiring obligations for self and others, guiding vision and informing compassion.

While almsgiving by a church, structured by this specific mode of covenantal thinking, has a rationale which is distinct from the way that funds for health and social care are codified and dispersed in a plural society through taxation, there are nonetheless observations which may be made by interrelating these modes of handling money through the theme of covenant.

First, far from being a judgment on those outside the new covenant and in a striking example of critical self-awareness, it is the church which Chrysostom warns about the temptations that arise in the context of money. In short, covenants should operate to dispel complacency about money and foster self-criticism of ways in which its presence in relationships provides opportunity for self-deception and temptation. 
Second, almsgiving in the church's story provides a core practice for preventing the distortions which inordinate attention to wealth and money can introduce. The practice is intended to represent the generosity of God by reflecting it, thereby fulfilling the purposes of the new covenant life into which the church was born. To be a faithful participant in a covenant is both to show trust in the God of the covenant and, only through the economy of grace that this God enacts, to become a trustworthy partaker of it by working to serve one's neighbours, especially with one's wealth. In this way, care and work are enfolded within the terms of the covenant that is enacted between God and the church and which forms a point of resistance to the service of Mammon against which Jesus warns.

With typical wisdom, Rabbi Sacks makes the congruent point that covenant has a power of a quite different order than money. Whereas, if 'I have a thousand pounds and share it with nine others ... I am left with a tenth of what I had', when I share certain kinds of goods such as friendship, kindness or love, I end up with more not less. The secret to this strange economy is to cultivate "environments in which we are bound to one another not by transactions of power or wealth but by hessed, covenant love ... God lives in the between that joins self to self through an act of covenant kindness' (Sacks 2005, p. 54; cf. Sacks 2000).

In similar ways, specific practices of health and social care will embody certain ways of either enabling covenant love or entrenching distortions of desire. Because of humanity's creation in the image of God within an orderly creation, mutuality, love and obligation are to mark such practices and the institutions the practices sustain. This is the basis for the possibility of the caring relationships Herring and Feiler - in their different ways - commend. Well-framed covenants give order to loving relationships within creation, thereby shaping the compassion that characterises persons and institutions.

\subsection{Covenant and marketisation}

This is not at all to suggest that it is inevitable that once 'covenant' is invoked, then money's mastery will be no more, bound by the covenant love and compassion in terms that Chrysostom and Sacks would commend. Not all summons to a covenantal mode of thinking and relating are equally illuminating.

For example, Rusthoven pays no sustained attention to marketisation's significance for a covenantal ethic in medicine. Commercial exploitation is discussed briefly only in relation to Islamic bioethics (Rusthoven 2014, p. 94). It is perhaps the lack of attention to the granularity of covenantal relations (e.g. between God and Israel) that led to this oversight, and it is an object lesson for any reference to covenant in health- and social care.

By contrast, William May, the forefather of twentieth-century covenantal thinking in healthcare, was explicit that the core rationale for thinking in covenantal terms is the threat to medical professionalism presented by marketisation. He identified the influence among U.S. doctors of increasingly commercialised representations of care in a minimalist, contractual way of conceiving relations between doctors and patients. While a legal contract has a proper place within healthcare 
to protect patients or doctors in some circumstances, it may introduce distortion when professional relations are reduced to the level of commercial contracts alone. (May 1975, pp. 33-35). In particular, a mere commercial-contractual model misses out on the 'element of the gratuitous' (ibid. p. 35) which covenants involve and the moral obligations which covenanting parties have towards each other.

In 1995, the drafters of the Patient-Physician Covenant gave further content to covenantal thinking by specifically targeting a 'growing legitimation of the physician's materialistic self-interest ... [and] for-profit forces [pressing] the physician into the role of commercial agent to enhance the profitability of health care organizations' (Crawshaw et al. 1995; cf. Misselbrook 2018, pp. 148-153).

For both May and the covenant drafters, covenantal language in some way reaches beyond normal human relations. Cassel, a co-author of the covenant, writes of a 'transcendent significance to the activities of healing', noting that while 'the physician's role in the lives of patients may not be godlike or divine, at its best it can and ultimately does have spiritual dimensions' (Cassel 1996, p. 605).

May is more theologically explicit than this somewhat anaemic reference to the 'spiritual', observing 'the secret root of every gift between human beings, of which the human order of giving and receiving could only be a sign' (May 1975, p. 35). With attention more granular than Rusthoven's, to the farming practices of Ancient Israel and their significance for sharing in the common wealth of the nation, May observes that the

ethic of service to the needy flowed from Israel's original and continuing state of neediness and indebtedness before God. Thus action which at a human level appears gratuitous, in that it is not provoked by a specific gratuity from another human being, is at its deepest level but gift answering to gift.

(ibid. p. 36, cf. Hordern 2013a)

Thus Israel, in their own internal practices, represents the gift they receive and so, ideally at least, model a life of gracious initiative.

This focus on obligation to others stemming from grace, articulated as a covenant which is closely attentive to economic realities, functions to sensitise May to the range of obligations at stake in a covenant specifically concerned with healthcare. He criticises the nineteenth-century American Medical Association's tendency to allocate 'duties' to physicians but 'obligations' to patients, not because it is improper to talk of patients' obligations but because the notion of doctors' duties as stated under-realised doctors' profound indebtedness to their society - with its universities and hospitals - and to their patients, who are willing to assist in their education, thereby providing the environment in which medical students could be trained and realise a useful social vocation (May 1975, pp. 31-32).

However, the Patient-Physician Covenant lacked this rooted granularity and omitted any attention to the obligations of patients and society or of the rationale for physicians' obligations to society, focussing solely on the 'covenant of trust with patients' as fulfilled by physicians. Cassel explains that central to the Covenant's rationale is 'the perceived threat ... to the sacred responsibility of 
physician to patient. The Covenant was crafted as a call to renew medicine's commitment to the core mission of concern for the sick and thus to maintain the soul of the medical profession' (Cassel 1996, p. 604). While the seed of the thought of a well-rounded perspective on obligation is clearly there in the Covenant, it has not come to maturity. ${ }^{3}$

By contrast, May's attentiveness to the range of obligations is rooted in a perspicuously Christian covenantal consciousness of the nature of love: 'not that we loved God but that he loved us' (1 John 4:10; May 1975, p. 36). For May, this recognition of the prevenient love of God both in an individual and across a society has concrete implications. Specifically, it generates an awareness of that which comes before our agency in the world, of that which we receive from others. In particular, this leads to a focus on the inherited nature of the societal conditions which enables physicians to flourish and which creates a sense of the reciprocal obligations that physicians and patients have with each other.

Such an awareness circumscribes the consciousness which doctors might have in entering a market for their services. The lack of balance between obligations which emerge in a condescending paternalism that pretends to a self-sufficient medical profession, free in the marketplace, is addressed by a covenantal sense of all of life as a gift from God, which is mediated through civilised ways of ordering life devised by humans and passed on to each succeeding generation. This does not rule out participation in selling one's services but makes such participation answerable to prior creaturely obligations.

On these two points, the granularity of the attention to economic realities and a focus on the obligations of all parties - especially those inherited by doctors - it is precisely the focus on specifically Jewish and Christian sources of covenantal thinking that makes May's account compelling. It is then to a fine-grained focus on specific kinds of covenant that we now turn.

\subsection{Comparing covenants}

Covenants, if well-framed, represent truthful ways of describing the relations between persons. Their pastoral strength and capacity to generate compassion lies in this kind of relational sensitivity. They can also tell a certain kind of political and economic story about a polity of citizens, whether that be ancient Israel or a modern nation-state. Parties to the covenant are made aware of the range and source of the obligations they have, the blessings they enjoy and the risks to those blessings if obligations are not fulfilled. By discerning obligations, blessings and risks within an historical narrative, attentive to hard-won institutional achievements that make possible a certain kind of civic life in which healthcare has a central role, the apparent inevitability of marketisation's mastery of human desires is challenged.

For Christian theology, it is precisely the historic nature of God's engagements with the creation in love, through Israel, Christ and the church, which sensitises people to such a covenantal consciousness. Covenantal thinking impels a critical engagement with the kind of story which has been told about the responsibilities 
and forms of gratuitous love and compassion which mark a relationship, a profession and a polity of citizens.

A well-framed covenant thus represents a certain kind of story based on how ecologies of mastery and service have come to evolve in any given culture, laying the basis for reappraisal, critique and resistance to 'inevitability' if a story has developed in a way which no longer enhances sharing in certain goods and wise debate about their nature and use. As stated earlier, "that which we serve will be determined in part by the representation of ourselves and our neighbours to which we subscribe". These self-understandings may change over time. Covenants have a peculiar capacity to challenge and to reorder such change.

A parallel which demonstrates the power of covenantal thinking to represent work, care and obligations and to shape self-understanding is the UK Armed Forces Covenant, referred to in the UK Armed Forces Act (2011). ${ }^{4}$ A key source of inspiration for the Armed Forces Covenant described how

mutual obligation forms the Military Covenant between the Nation, the Army and each individual soldier; an unbreakable common bond of identity, loyalty and responsibility which has sustained the Army throughout its history.

(UK Ministry of Defence 2000)

The Covenant pays particular attention to these mutual obligations which government representing society and service personnel owe to each other. The armed forces' obligations are focussed on tasks which they commit to fulfil, often at significant risk, in bearing arms and undertaking other politically authorised activities. Societal and governmental obligations are focussed on the welfare of service personnel and their families in light of the risks to which they are exposed and sacrifices which they make on behalf of their nation and other nations.

For both parties, there is an element of gratuity which goes beyond anything a contract can require: the obligations owed to the armed services are supported by, but never entirely exhausted by, specific legal provisions. Creativity is needed to discern how best to fulfil the covenant at the social and moral level, especially in terms of according respect and honour to armed forces personnel and families. The obligations owed by members of the armed services are distinctively gratuitous in that they in principle commit to hold nothing back, even their lives.

Healthcare services also involve sacrifice and risk, even risk to one's own life, albeit to a lesser extent. Though the bullet-wound and needle-stick injury differ in the scale of risk they pose, there is nonetheless a shared exposure to threats undertaken on behalf of others. Where health is nationalised, both forms of service represent a nation inasmuch as the work which they do and the loving care with which they do it tells a certain kind of story about the identity of a polity and what it may require of its people. Both have, for many years at least, warranted respect and honour to those who provide them.

Not for nothing are the armed services central to UK national celebrations and commemorations. Not for nothing was the National Health Service at the heart of the 2012 London Olympic opening ceremony. And not for nothing do failures 
to keep covenant by healthcare staff (e.g. surgical misconduct) and armed forces personnel (e.g. extra-judicial killings) strike at the core of the national psyche, causing a breach in existing covenantal relations, whether tacit or explicit. Both sets of professionals embody forms of service which are central to the contested story the United Kingdom tells about itself and which becomes explicit when the occasion requires that the nation becomes self-conscious. These professions'very institutional lives represent a kind of self-image to which the nation is summoned to debate and defend.

Just how sacrifice and risk figure in the service represented in these institutions of national life of particular importance to the devising of any prospective healthcare covenant. The obligations inherent in the Armed Forces Covenant focus squarely on the welfare of armed services personnel and their families in light of the risks they face. Because of the nature of the work which the armed forces do, this is entirely appropriate. The extreme sacrifice which energises the mutuality that is the background assumption of the Covenant is the basis for this concern for welfare.

Any prospective healthcare covenant would not be so straightforwardly focussed on the welfare of health and care workers and their families, even bearing in mind the risky possibilities of such work. Nonetheless, there are threats to human wellbeing which the profession of medicine commits a health or care worker to encounter. In such a covenant, when professionals and patients keep their mutual obligations, they keep them not just with each other but also with society as a whole, since the pains and costs of ill health are born not just by individuals but also, in some sense, by the whole community.

So it seems imperative that an emphasis on workers' welfare should be included both in covenantal thinking and in any written articulation of covenantal relations. Welfare in this case would pay attention especially to the form of the working conditions, the provision for dependents and the commitments of patients and managers to staff which are promised. Among armed forces personnel, esprit de corps and camaraderie are cemented by the extreme kinds of threats to their lives as well as those of others that they encounter together, commonly yielding remarkable regimental loyalties. Since, in healthcare, the normal threat is to others' lives, a key covenantal focus should be on the risk to workers' wellbeing, which encounters with suffering and death on a nation's behalf engender.

In summary, the terms of a covenant and, crucially, the manner in which a covenant is implemented, tells a certain kind of story about a polity - what it values, what it loves, what sacrifices it will make and why it will be committed to maintaining those sacrifices amidst hardship. Just as the UK Armed Forces Covenant is intended to fit the specific nature of armed service in the context of a nation's historical circumstances, so also a Healthcare (or Health and Care) Covenant would fit the specific nature of healthcare service in the context of a nation's historical circumstances, reacting to certain problems and fending off certain dangers. The specific nature of a certain profession's work of care is the key determinant for the shape of any covenant. What is decisive is the kind of political story which a covenant tells, in its formulation, in its practical outworking and in the breach - when commitment to covenant fails. 
Returning explicitly to our theme of marketisation, a covenant should stress that to be mastered by money threatens that desire for service which strengthens the self-understanding of a profession or nation. To serve Mammon as master puts pressure on the possibility of covenantal relations of care and work shaped by gratuity as opposed to solely contractual obligation. Government is a key broker in seeking to fend off the temptations which can attend the presence of money in covenantal relationships.

\subsection{Five requirements for a healthcare covenant}

What requirements should shape a Healthcare Covenant, written and owned by all parties, which attends wisely to the challenges and opportunities of marketisation? What covenantal provisions or emphases would sustain regard, guide perception into truth, restrain distortion and order compassion aright?

\section{First, a healthcare covenant should deploy historical sensitivity in bind- ing all parties together in order to bind the tendency to distortion of desire which accompanies money's presence.}

Distorted desires and modes of practice should be addressed by the articulation and institutional embodiment of certain deep commitments which both tell the truth about the development of a story and write a new and better chapter. On Feiler's view, the acceptance of DRGs has created a certain kind of ahistorical consciousness on the part of those who administer them, concealing the origins of the codification, making invisible the care of those who are codified and abandoning those same people to the drivers which the codification brings about. And yet, as Feiler comments, 'historically grown healthcare systems are always already the result of (potentially religiously grounded) truth commitments - anthropological, political, eschatological' (internal reference Feiler). The healing which healthcare requires is in part one which achieves the hope of reconciliation between those persons who have become hidden from each other, submerged beneath an apparently inexorable, never-ebbing tide of monetisation.

\section{Second, the historic indebtedness of each physician, who is depend- ent on both patients and the existing healthcare infrastructure for training and for ongoing opportunities to perform meaningful work, should be basic to any covenant.}

This emphasis follows on but fills out some detail of Feiler's important but as yet somewhat abstract claims. Nigel Biggar makes a similar point in his perception of the debt of gratitude that each generation owes to that which precedes it, grounding a sense of obligation especially to one's nation (Biggar 2014). This is an important argument against conceiving healthcare staff as wandering healers-for-hire, a problem especially pertinent to doctors in underfunded state-run organisations such as the NHS. This dimension of marketisation is perhaps most damaging in the context 
of a socialised system such as the British NHS, in which significant taxpayer funding is deployed to subsidise doctors' training when their future employment by the state is not guaranteed.

\section{Third, covenantal thinking implies responsibility-taking by all parties, including the patient, for their and others' welfare, including the welfare of healthcare workers.}

May emphasises the image of the patient as 'active participant both in the prevention and the healing of the disease. He must bring to the partnership a will to life and a will to health' (May 1975, p. 36). For some, the personal budgets policy provided just the opportunity for that active participation and collaboration with health and care workers.

However, Rusthoven comments that the increased interest in covenantal models coincides with efforts to address the overemphasis on patient autonomy that has largely replaced traditional paternalism' (Rusthoven 2014, p. 136). Enraptured with an emphasis on purely self-sacrificial agape love as the basis of covenantal care as distinct from the reciprocal hessed Sacks commends, he claims that 'reciprocation should not be a necessary and expected outcome. The scriptural mandate to help others and to show mercy must remain in the foreground' (ibid. p. 256).

While it is true that despite 'human failure to maintain obedient obligations to that covenant, God has repeatedly shown his faithfulness to that covenant' (ibid. p. 260), 'the sacrifice and selflessness that mark a covenantal approach to health care' (ibid. p. 264) by no means entail the exclusion of the reciprocity that properly marks a healthcare covenant. Moreover, this means not only taking responsibility for one's own well-being but also, developing Herring's thought, that of those participating in a caring relationship with you. The parallel with the Armed Forces Covenant is particularly relevant here as a basis for societal obligations to partner with and ensure the welfare of healthcare workers as they encounter their neighbours' suffering and death. By contrast, 'defensive medicine', as discussed by Jani and Papanikitas (2018), represents a cultural aversion to, and abdication of, responsibility-taking in favour of self-protective practices, characterising not only clinicians but also whole institutions.

\section{Fourth, while responsibility-taking is core to covenant, covenan- tal thinking must also be defined by grace and flexible enough to encourage discretion in individual circumstances.}

Herring's rather critical approach to personal budgets surely has some traction here. The practical outworking of the scheme seems to have included at least something of the sense of being abandoned to one's own autonomy rather than the relational autonomy Herring commends. Some local authorities seem to have been glad to shift responsibility more or less wholesale - so to speak - from their institutions to citizens' shoulders, be they strong or weak. This is a general 
temptation which accompanies forms of marketisation that place the burden on the 'consumer' - caveat aeger ("let the sick person beware")!

Recalling John Chrysostom's concern to bind money's power in the church, what covenantal thinking highlights is the danger of leaving people isolated with responsibility for money - the hazard of a mere contract which is neither fitted to the person nor in any way gracious. Covenantal thinking encourages responsibility for the work of care to be distributed in a supportive way, specific to the person at hand.

Moreover, it is the ultimately non-contractual nature of the covenant which allows discretionary sensitivity to the capacities of the individual rather than an allor-nothing requirement. While covenant involves gratuity, it also involves sensitivity to specific circumstances, making it so eminently suitable for a personalised healthcare which is underwritten and circumscribed by a covenanting community.

Honest conversation with patients about errors as recommended by Jani and Papanikitas (2018) would also be a feature of a gracious covenantal relationship. In the context of covenant, it is possible not only to take responsibility for errors in relation to individuals who suffer its effects but also to construe error in relation to community benefit. Processes for reporting error can be gracious towards health professionals' errors while candid with those affected. But these processes will work best if the relationship between healthcare professionals and society is not conceived solely in terms of contract, with its inbuilt logic of defensiveness and litigation, but primarily as a long-term learning covenant.

\section{Fifth, a covenant must be explicit about the implications of failures to keep covenant.}

In ancient Israel, one of the characteristics of the covenantal relationship between God and his people was the provision of curses which would come upon the people pursuant to their failures to be faithful and loyal (e.g. Deuteronomy 27-30). A curse amounting to a loss of honour represents the final words of the Hippocratic Oath.

A distinctive feature of any prospective healthcare covenant is most clearly seen when one considers that the penalties for failures in keeping obligations within a covenant are found in the consequences experienced by all concerned rather than in sanctions applied to any particular individual. In other words, failures in responsibility will often have significant social implications. Just as armed service is not private - or at least is never of private significance alone - so healthcare is not private - or at least is never of private significance alone. This is more explicit in a socialised health system in which a limited fund must cover the entire population's need. But even in a private insurance based system, it is clear that premiums payable will depend, to some degree, on the actions of all, and that bad outcomes to healthcare, while impacting individuals primarily, also have social ramifications.

In summary, a Healthcare Covenant should be psychologically astute about the historic context in which marketisation processes are operative; attentive to the historic indebtedness of health- and social care workers in order to challenge a pure free agent mentality; unembarrassed about the obligations of all parties, including 
patients' obligations for the welfare of themselves and their carers; full of grace and discretion when it comes to individual circumstances; and explicit about what follows from failures in covenant.

A covenant thus characterised will guard against the pendulum swinging between extremes of ahistorical consciousness/uncritical conservatism, marketised ultra-mobility/stultifying statism, autonomy/paternalism, pure self-sacrifice/ merely contractual reciprocity and legalism/license. It does so by keeping the different kinds of responsibility bound together in a single, if contested, narrative, with a view to ensuring that money never masters but rather is mastered by a community of compassion and grace.

\section{Conclusion: mastering Mammon, renewing compassion}

Just as in the case of the contrast of Rusthoven and May, it would be an overstatement to suggest that an appeal to the notion of covenant is a simple solution to the systemic problems which Feiler and Herring identify in the concrete practices of marketisation that they consider. The outworking of the Armed Forces Covenant as a social or moral matter rather than a merely legal one bears witness to the challenges on the level of policy which covenants require.

What a well-framed, written, legally backed covenant can achieve is a stable sensitivity to the threats which would obscure or undermine the relationships of mutual obligation, embedded in specific practices of relational care, which the covenant seeks to preserve. A covenant explicitly makes visible and valorises these practices which constitute the institutions - such as hospitals, local authorities and providers of social care - which shape a people's civic life. These institutions are then the formal manner of representing in practice a covenant that restrains the love of money, makes visible those relationships which ought not to be obscured, denies the supremacy of choice in a market to the exclusion of care and articulates the architecture of obligation. Indeed, a covenant which is not enacted in practice is hardly worthy of the name. Through healthy, wise institutions, money may be mastered through the moral and social power of a covenant whose realisation binds money's power and brings to conscious awareness the persons with whom one is in promissory relations.

With respect to defensive medicine, Jani and Papanikitas (2018) judiciously lay out some of the policy approaches which could address the tendencies that undermine trust between doctors and patients. They are conscious that the pursuit of worthy goals can give grounds for entrenching defensiveness, and that any payment model, however carefully devised, is subject to abuse. What is required to direct goals and to cement trust is not only a wiser payment model and not only an emphasis on safety, quality and efficiency. More fundamentally, what is required is that healthcare relationships are conceived in a way which promise that the presence of Mammon will not overwhelm the encounter of persons which is at the heart of covenantal healthcare.

Such an approach in no way requires that covenants in respect to health and social care be solely formed on a national level or be restricted to relations between 
citizens and state institutions. Indeed, the focus of covenants on relationships which transcend the contractual would lend itself well to the more localised and personalised forms of care relations which personal budgets are meant to facilitate. That which can be captured in a commercial contract would very likely fall far short of what is required. Dancing Sally can contract for her assistant to put in the hours and take her to the dancehall. But she could hardly contract that her assistant dance the waltz with her on occasion, and still less, do so 'with feeling'.

In limiting the power of Mammon and its modes of measurement to influence ways of perceiving and caring for people, covenants reorder loves. That which draws attention away from the suffering of the persons for whom one is called to care is that which should be resisted through the terms of covenant. To reorder loves in service of those who suffer is to renew compassion. It is therefore a covenant of compassion which can resist the temptations which lurk within the marketisation process. Equally, it is a covenant of compassion which can guide that personalisation of care that properly serves individuals in their circumstances.

Accordingly, health- and social care professionals should seek to form and enter into covenants which bear witness to a certain kind of story about a compassionate common life. In the terms of a political and pastoral theology, the covenant between healthcare professionals and society should be in some sense a reflection of the covenant between God and his people - Israel and the church. This reflection will be imperfect because of the difference between the parties covenanting in the two cases. But there will also be a similarity inasmuch as the covenant is formed amidst suffering and over against the dangers of isolation and abandonment to lonely and arbitrary choice.

Such covenants are defences against the corrosive elements in healthcare marketisation processes which Walsh identifies (Walsh 2018). It is not that there is a total incompatibility between service and commercialisation, or indeed between serving and measuring. Rather, the question is which master is served and what money is made to follow. In the words of the Archbishop of Canterbury, it is a matter of making money serve grace. Some mix of moral persuasion and legal sanction is Walsh's recipe for moral rectitude. While this is welcome, it seems inadequate to shape healthcare work, especially when it is compared to the work of the armed services. A covenant based on gracious interrelations and the taking of responsibility seems best fitted to foster the sensitivity and resistance to corrosion for which Walsh hopes.

The relational life which a covenant envisages is properly called 'communion'. In the life of the church for whom Chrysostom preached, this was a holy communion, the life of the church set apart by God to resist Mammon's mastery. However, as I have explained elsewhere, the nature of communion in a plural political society is not holy but tense (Hordern 2014). Health- and social care institutions embody, at least in plural Western democracies, the meeting point of many different ways of communing in humanity's suffering condition. The specific terms of a covenant in a plural society, precisely because they require an internalised acceptance - a matter of the heart - cannot be those which necessarily require confession of faith in the God revealed in Jesus Christ. However, as I have argued here, a wise 
conception of a covenant which will aid health- and social care today, especially amidst the challenges and opportunities of marketisation, is best arrived at by drawing inspiration from Jewish and Christian sources of covenantal consciousness and compassionate practice.

\section{Notes}

1 Joshua Hordern's work is supported by the University of Oxford Wellcome Trust Institutional Strategic Support Fund (105605/Z/14/Z) and the Arts and Humanities Research Council (AH/N009770/1). The author gratefully acknowledges this funding and also that of the British Academy and the Sir Halley Stewart Trust. The views expressed are those of the author and not necessarily those of the Sir Halley Stewart Trust.

2 'Multivariate analyses of the structured interview data showed that IBs were associated with positive impacts on carers' quality of life, social care outcomes and psychological well-being. In relation to all these outcome measures, carers of IB users scored higher than carers of people using standard social care services; the difference between the two groups of carers was statistically significant in relation to carers' quality of life' (ibid. p. 89).

3 For example, it has been reaffirmed in its original form, by the American Psychiatric Association, in both 2007 and 2014. See www.psychiatry.org/File\%20Library/AboutAPA/Organization-Documents-Policies/Policies/Position-2014-Patient-PhysicianCovenant.pdf.

4 Different questions naturally arise regarding marketisation since there is nothing like the need for a state monopoly on healthcare provision when compared with the need for a near or total monopoly on the use of armed force, although there is a growing market for private armed contractors.

\section{References}

Baxter, K. and Glendinning, C. (2013). The Role of Emotions in the Process of Making Choices about Welfare Services: The Experiences of Disabled People in England. Social Policy \& Society 12:3: 439-450.

Biggar, N. (2014). Between Kin and Cosmopolis: An Ethic of the Nation. Eugene, OR: Cascade.

Cassel, C. (1996). The Patient-Physician Covenant: An Affirmation of Asklepios. Annals of Internal Medicine. 124: 604-606.

Chrysostom, J. (1839). The Homilies of John Chrysostom. Oxford: Parker.

The Church of England (2017). Book of Common Prayer. Cambridge: Cambridge University Press.

Crawshaw, R., Rogers, D.E., Pellegrino, E.D., Bulger, R.J., Lundberg, G.D., Bristow, L.R. et al. (1995). Patient-Physician Covenant. Journal of the American Medical Association 273: 1553 .

Feiler, T. (2018). Encoding Truths? Diagnosis-Related Groups and the Fragility of the Marketisation Discourse. In: Feiler, T., Hordern, J., and Papanikitas, A. (eds.) Marketisation, Ethics and Healthcare: Policy, Practice and Moral Formation. Abingdon: Routledge, pp. 67-83.

Glendinning, C., Arksey, H., Jones, K., Moran, N., Netten, A., and Rabiee, P. (2009). The Individual Budgets Pilot Projects: Impact and Outcomes for Carers. York: University of York/University of Kent.

Herring, J. (2018). Personal Budgets: Holding onto the Purse Strings for Fear of Something Worse. In: Feiler, T., Hordern, J., and Papanikitas, A. (eds.) Marketisation, Ethics and Healthcare: Policy, Practice and Moral Formation. Abingdon: Routledge, pp. 84-98. 
Hordern, J. (2013a). Political Affections: Civic Participation and Moral Theology. Oxford: Oxford University Press.

Hordern, J. (2013b). What's Wrong with "Compassion"? Towards a Political, Philosophical and Theological Context. Clinical Ethics 8.4: 109-115.

Hordern, J. (2014). Loyalty, Conscience and Tense Communion: Jonathan Edwards Meets Martha Nussbaum. Studies in Christian Ethics 27.2: 167-184.

Hordern, J. (2017). Compassion in Primary and Community Healthcare. In: Papanikitas, A. and Spicer, J. (eds.) Handbook of Primary Care Ethics. London: CRC Press: 25-33.

Jani, A. and Papanikitas, A. (2018). "More Than My Job Is Worth": Defensive Medicine and the Marketisation of Healthcare. In: Feiler, T., Hordern, J., and Papanikitas, A. (eds.) Marketisation, Ethics and Healthcare: Policy, Practice and Moral Formation. Abingdon: Routledge, pp. 99-110.

May, W. (1975). Code, Covenant, Contract or Philanthropy. Hastings Center Report 5: 29-38.

McCann, L., Granter, E., Hassard, J., and Hyde, P. (2015). "You Can't Do Both - Something Will Give": Limitations of the Targets Culture in Managing UK Health Care Workforces. Human Resource Management 54:5: 773-791.

Misselbrook, D. (2018). The Virtuous Professional and the Marketplace. In: Feiler, T., Hordern, J., and Papanikitas, A. (eds.) Marketisation, Ethics and Healthcare: Policy, Practice and Moral Formation. Abingdon: Routledge, pp. 147-162.

Petratos, P. (2018). Why the Economic Calculation Debate Matters: The Case for Decentralisation in Healthcare. In: Feiler, T., Hordern, J., and Papanikitas, A. (eds.) Marketisation, Ethics and Healthcare: Policy, Practice and Moral Formation. Abingdon: Routledge, pp. 13-31.

Roland, M. (2012). Incentives Must Be Closely Aligned to Professional Values. British Medical Journal 345: e5982.

Rusthoven, J. (2014). Covenantal Biomedical Ethics for Contemporary Medicine: An Alternative to Principles-Based Ethics. Eugene, OR: Pickwick.

Sacks, J. (2000). The Politics of Hope. London: Vintage.

Sacks, J. (2005). To Heal a Fractured World: The Ethics of Responsibility. New York: Continuum.

UK Ministry of Defence (2000). Soldiering: The Military Covenant. London: Army Doctrine Publication, Volume 5.

Walsh, A. (2018). Commercialisation and the Corrosion of the Ideals of Medical Professionals. In: Feiler, T., Hordern, J., and Papanikitas, A. (eds.) Marketisation, Ethics and Healthcare: Policy, Practice and Moral Formation. Abingdon: Routledge, pp. 133-146.

Welby, J. (2016). Dethroning Mammon: Making Money Serve Grace. London: Bloomsbury. 